\title{
IMPLEMENTASI PEMBELAJARAN PAI SERTA PENANAMAN TOLERANSI BERAGAMA PADA SD FRANSISKUS PADANG PANJANG
}

\author{
Azwarhadi \\ Kepala Tata Usaha MTs Negeri 1 Ganting, Padang Panjang \\ e-mail: ahkumis@gmail.com
}

\begin{abstract}
This research was aimed at undertanding the implementation of instructional Islamic Education in Primary School Fransiskus Padang Panjang, the non Islamic institution. This research was qualitative by applying interview as instrument. The results obtained indicate that the Primary School Fransiskus Padang Panjang gave good service for Islamic students to learn Islamic Education.
\end{abstract}

Keywords: Implementasi, Pendidikan Agama Islam, Toleransi Beragama

PENDAHULUAN

Pendidikan merupakan hak setiap manusia, termasuk hak mendapat pendidikan agama bagi setiap penganut agama yang diakui eksistensinya di Negara Kesatuan Republik Indonesia. Pengelola lembaga pendidikan wajib memberikan pendidikan agama sesuai agama yang dianut siswa. Pendidikan agama merupakan salah satu mata pelajaran wajib yang harus diikuti oleh setiap siswa di sekolah pada semua jenjang, yaitu SD, SLTP dan SLTA maupun perguruan tinggi. Secara yuridis, ketentuan ini tertuang dalam Undang-undang Nomor 20 Tahun 2003 tentang Sistem Pendidikan Nasional (SISDIKNAS), pasal 13 huruf a mengamanatkan: "Setiap peserta didik pada setiap satuan pendidikan berhak mendapatkan pendidikan agama sesuai dengan agama yang dianutnya dan diajarkan oleh pendidik yang seagama." (UU Sisdiknas, 2010 : 170).

$$
\text { Undang-Undang mengisyaratkan }
$$

seluruh lembaga pendidikan berkewajiban memenuhi kebutuhan masyarakat dalam hal pendidikan agama sesuai dengan keyakinannya dan oleh guru yang seagama dengan peserta didik. Baik lembaga pendidikan umum maupun lembaga pendidikan yang berciri keagamaan. Pendidikan Agama Islam hendaknya ditanamkan sejak masa anak-anak, sebab pendidikan masa anak-anak menjadi dasar yang akan menentukan pendidikan selanjutnya. Menurut Daradjat (1991: 48) bahwa pada umumnya agama seseorang ditentukan oleh pendidikan, pengalaman dan latihan yang dilaluinya sejak kecil.

Pendidikan Agama Islam diberikan dengan mengikuti tuntunan yang bersumber dari al-Qur'an dan As Sunnah. Menurut Langgulung (2010: 75) bahwa sumber pendidikan Islam yaitu al-Qur'an, As Sunnah, 
ucapan para sahabat (mazhab sahabi), kemaslahatan ummat (masalih al mursalah), tradisi atau adat yang sudah dipraktekan dalam kehidupan masyarakat (al-'urf), dan hasil ijtihad para ahli. Selanjutnya, Pendidikan Agama Islam adalah upaya sadar dan terencana dalam menyiapkan peserta didik untuk mengenal, memahami, menghayati hingga mengimani ajaran agama Islam diikuti dengan tuntunan untuk menghormati penganut agama lain dalam hubungannya dengan kerukunan antar umat beragama, hingga terwujud kesatuan dan persatuan bangsa (Madjid dan Dian, 2005:130).

Keberadaan Indonesia sebagai sebuah bangsa yang pluralis, dihuni oleh berbagai suku, budaya, ras, bahasa dan agama menyebabkan Indonesia rentan terhadap muncul berbagai konflik. Di antara potensi konflik tersebut, yang sangat mudah disulut oleh api perpecahan adalah konflik atas nama agama. Di Indonesia memang mayoritas muslim, namun keberadaan agama lain seperti Katolik, Kristen, Hindu, Budha dan Konghucu diakui dan dilindungi secara resmi. Artinya Indonesia merupakan negara majemuk secara suku bangsa, budaya dan agama. Dari kacamata Islam, kemajemukan dan keberagaman merupakan bagian dari Sunnatullah sebagaimana firman Allah SWT dalam al-Qur'an QS: 49 : 13 “Hai manusia, sesungguhnya kami menciptakan kamu dari seorang laki-laki dan seorang perempuan dan menjadikan kamu berbangsa-bangsa dan bersuku-suku, supaya kamu saling mengenal. Sesungguhnya Allah Maha Mengetahui lagi Maha mengenal".

Ayat di atas membuktikan bahwa pluralitas merupakan sebuah keniscayaan yang tidak dapat dihindarkan yang harus diterima sebagai sebuah kenyataan dengan penuh lapang dada. Menurut Azizy (2005: 1) perbedaan konsepsi di antara agama-agama yang ada adalah sebuah realitas, yang tidak dapat dipungkiri oleh siapa pun. Perbedaan bahkan benturan konsepsi itu terjadi hampir semua aspek agama, baik bidang konsepsi tentang Tuhan maupun konsepsi pengaturan kehidupan. Pendapat senada dari Amstrong (2001: 27) yang menyatakan bahwa agamaagama besar di dunia memiliki konsepsi yang beragam dan persepsi yang berbeda tentang Tuhan.

Kemajemukan yang dimiliki bangsa Indonesia satu sisi merupakan modal besar, namun di sisi lain merupakan potensi konflik antar ummat beragama. Tilaar (2004: 37) menyatakan bahwa masyarakat multikultural sebenarnya menyimpan banyak kekuatan dari masing-masing kelompok, namun disatu sisi juga menyimpan benih perpecahan apabila tidak dikelola dengan baik dan rasional. Secara etimologi, multikulturalisme dibentuk 
dari kata multi (banyak), kultur (budaya), dan isme (aliran/paham). Secara hakiki, dalam kata itu terkandung pengakuan akan martabat manusia yang hidup dalam komunitasnya dengan kebudayaannya masing-masing yang unik (Mahfud, 2006: 75). Sedangkan kultur itu sendiri tidak bisa terlepas dari empat tema penting yaitu agama (aliran), ras (etnis), suku, dan budaya. (Dawam, 2003: 99-100) Multikulturalisme secara filosofis pada dasarnya merupakan pandangan yang meyakini bahwa dalam realitas kehidupan terdapat keragaman (diversity) atau kemajemukan (plurality) kebangsaan, ras, suku, bahasa, tradisi, agama, kepentingan dan sebagainya yang harus dihormati diakui, atau difungsikan (Yusuf, 2006: 21). Mulkhan (2005: 7) mengemukakan bahwa multikulturalisme adalah gagasan yang lahir dari fakta tentang perbedaan antar warga masyarakat bersumber etnisitas bersama kelahiran sejarah.

Mengingat keberagaman dan kemajemukan tersebut, semua pihak harus menanamkan dan mengembangkan budaya toleransi. Toleransi mengarah kepada sikap terbuka dan mau mengakui adanya berbagai macam perbedaan,baik dari sisi suku bangsa, warna kulit, bahasa, adat istiadat,budaya, bahasa, serta agama. Dalam Kamus Bahasa Indonesia dijelaskan bahwa toleransi, berasal dari dua kata "perilaku dan toleran", kata "perilaku" merupakan jenis kata benda, yang memiliki arti "tanggapan atau reaksi terhadap rangsangan atau lingkungan". Selanjutnya kata "toleran" merupakan kata sifat yang memiliki arti "bersifat atau bersikap menenggang (menghargai, membiarkan, membolehkan) pendirian (pendapat, pandangan, kepercayaan, kebiasaan, kelakuan, dan sebagainya), yang berbeda atau bertentangan dengan pendirian sendiri. Sedangkan kata "toleransi" merupakan kata kerja yang memiliki tiga makna yaitu: 1) sifat atau sikap toleran; 2) batas ukur untuk penambahan atau pengurangan yang masih diperbolehkan; 3) penyimpangan yang masih dapat diterima dalam pengukuran kerja. Prinsip mengenai toleransi antar umat beragama yaitu 1) tidak boleh ada paksaan dalam beragama baik paksaan itu berupa halus maupun dilakukan secara kasar; 2) manusia berhak untuk memilih dan memeluk agama yang diyakininya dan beribadat menurut keyakinan itu; 3) tidak akan berguna memaksa seseorang agar mengikuti suatu keyakinan tertentu; dan 4) Tuhan Yang Maha Esa tidak melarang hidup bermasyarakat dengan yang tidak sefaham atau tidak seagama, dengan harapan menghindari sikap saling bermusuhan (Ali, 1986: 82). Bentuk toleransi yang harus ditegakkan yaitu 1) toleransi agama dan 2) toleransi sosial. Toleransi agama adalah toleransi yang 
menyangkut keyakinan yang berhubungan dengan akidah yaitu sikap lapang dada untuk memberi kesempatan pemeluk agama selain Islam beribadah menurut ketentuan agama yang diyakininya. Sedangkan, toleransi sosial berorientasi terhadap toleransi kemasyarakatan. Dalam masyarakat yang beragam karena perbedaan agama dianjurkan untuk menegakkan kedamaian dan melakukan kerjasama dengan orang-orang yang berlainan agama dalam batas-batas yang telah ditentukan.

Praktik pelaksanaan pendidikan agama Islam di SD Fransiskus yang merupakan sekolah non muslim menarik untuk di dalami. Di sekolah tersebut, diberikan pendidikan agama Islam untuk anak-anak muslim. Karena kenyataannya, di SD Fransiskus jumlah siswa muslim separoh dari jumlah siswa. Adapun guru pendidikan agama Islam untuk memberikan pembelajaran agama Islam bagi siswa yang beragama Islam adalah guru yang telah disediakan dan disiapkan oleh sekolah. Selain itu, dari hasil wawancara yang peneliti lakukan, menunjukkan pelaksanaan pembelajaran PAI pada sekolah non muslim memiliki karakteristik dan keunikan tersendiri dibandingkan dengan pelaksanaan pendidikan Agama Islam di sekolah umum lainnya atau madrasah pada umumnya.

Untuk memudahkan koordinasi dalam pengelolaan dan pelaksanaan Pendidikan
Agama Islam tersebut, Kepala Sekolah menunjuk seorang wakil Kepala Sekolah dari salah seorang guru yang beragama Islam. Sebab arah pengelolaan sekolah non muslim, sebagai lembaga pendidikan berciri khas agama, cenderung mengacu pada sistem ideologi yang telah menjadi sistem keyakinan. Kebijakan sekolah, model interaksi antar warga sekolah, serta pembentukan lingkungan pendidikan dilakukan sesuai ideologi yang telebur dalam visi dan misi sekolah.

SD Fransiskus yang berada di bawah yayasan prayoga. Sebagai lembaga pendidikan yang selalu eksis di tengah kehidupan masyarakat yang mayoritas muslim, mendorong penulis untuk melakukan penelitian tentang bagaimana manajemen pengelolaan dan pelaksanaan pendidikan Agama Islam bagi peserta didiknya yang beragama Islam. SD Fransiskus adalah lembaga pendidikan swasta yang berdiri tahun tahun 1957 beralamat di Jalan K.H. Ahmad Dahlan No. 4 Kelurahan Balai- Balai Kecamatan Padang Panjang Barat.

Keberadaan SD Fransiskus sebagai lembaga pendidikan swasta dari sebuah yayasan non muslim di Kota Padang Panjang dengan penduduk mayoritas muslim dan berjulukan Serambi Mekkah, menarik untuk dijadikan objek penelitian, terutama dalam hal pelaksanaan pendidikan agama Islam. SD Fransiskus tersebut dibangun pada tahun 1957 
oleh Pastor Mario Boggioni. Kini SD Fransiskus berada dalam naungan Yayasan Prayoga yang berpusat di Padang. Bangunan yang pertama kali digunakan menjadi ruang kelas adalah aula Gereja St.Theresia. Lalu pada tahun 1968 dibangun gedung kelas baru yang terletak di belakang dan kanan gereja. Kelas tersebut terdiri atas dua lantai, lantai pertama terdiri dari empat ruang kelas yang digunakan sebagai ruang kelas 1, 2, 3 dan ruang belajar TK Petrus. Sedangkan lantai 2 digunakan sebagai ruang kelas 4,5,6 dan ruang komputer. Ruang komputer itu berisi 17 unit komputer. Bukan jumlah yang banyak untuk sebuah Yayasan. Namun dimanfaatkan dengan maksimal oleh pihak sekolah, dengan mengadakan jam tambahan mata pelajaran komputer.

Di tiap kelas disediakan satu rak khusus untuk menempatkan bekal makanan yang dibawa para siswa. Pihak sekolah memang mengharuskan siswanya untuk membawa air minum mereka masing-masing. Tidak jarang juga beberapa siswa dibawakan bekal oleh orangtua mereka, melihat jam pelajaran yang terkadang sampai pukul setengah tiga siang. Waktu normal proses belajar mengajar berakhir pukul satu siang. Namun pihak sekolah juga menyediakan jam tambahan belajar bagi siswanya. Keberadaan salib di dinding depan kelas mengingatkan kembali bahwa sekolah tersebut merupakan sekolah Katolik. Walaupun saat ini 62\% dari jumlah siswanya beragama Islam. Sedangkan siswa beragama Kristen Protestan berjumlah 38 orang, Kristen Katolik berjumlah 42 orang dan 3 orang siswa yang beragama Buddha. Hanya ada 10 orang guru yang bekerja di Sekolah ini. Tujuh orang di antaranya beragama Islam. Dari para guru mereka, siswa meniru sikap toleransi yang harus mereka miliki (Studi Dokumentasi, Media Pijar, 20 Desember 2013).

Karena siswa yang belajar di SD Fransiskus tidak hanya dari kalangan keluarga Kristen, tetapi anak-anak dari kalangan keluarga muslim. Keberagaman siswa tidak hanya nampak dari segi agama saja, melainkan dari segi suku, etnis, dan sosial ekonomi. Dari kacamata muslim, bahwa pendidikan setiap anak akan akan mempengaruhi masa depannya. Asumsi masyarakat, bahwa dengan memasukan anakanak untuk dididik di sekolah non muslim, sama saja dengan mengorbankan aqidahnya. Tetapi kenyataannya di SD Fransiskus, bagi anak-anak yang berasal dari keluarga muslim juga diberikan pelajararan pendidikan Agama Islam. Berdasarkan wawancara peneliti dengan kepala SD Fransiskus Lina Lindayanti Usman dan guru Pendidikan Agama Islam Purnama Indah Sari, S.Pd.I menyampaikan bahwa pelaksanaan pembelajaran PAI sama dengan yang dilaksanakan pada SD lainnya 
yang ada di Kota Padang Panjang. Karena kepala sekolah senantiasa mengikuti rapat periodik setiap bulan dengan kepala-kepala $\mathrm{SD}$, kemudian guru PAI juga aktif dalam pertemuan Kelompok Kerja Guru (KKG) setiap bulannya.

\section{METODE PENELITIAN}

Metode penelitian yang digunakan adalah deskriptif. Sebagaimana dikemukakan oleh Sukardi (2008: 157) bahwa penelitian metode deskriptif merupakan metode penelitian yang berusaha menggambarkan dan menginterpretasi objek dengan apa adanya. Metode ini tepat digunakan, karena penelitian ini mengambil masalah yang berkenaan dengan keadaan yang sedang terjadi.

Pendekatan penelitian kualitatif ini bertujuan untuk mengungkap data yang ada di lapangan, dengan cara menguraikan dan menginterpretasikan sesuatu seperti apa adanya (alamiyah). Sedangkan untuk mengolah data yang menunjang terhadap penelitian, peneliti menggunakan teknik pengumpulan data melalui wawancara.

\section{HASIL PENELITIAN DAN PEMBAHASAN}

1. Terminologi Pendidikan Agama Islam

Dalam Undang-Undang Nomor 20 tahun 2003 tentang Sistem Pendidikan Nasional, terutama pada penjelasan Pasal 37 ayat (1) bahwa pendidikan agama dimaksudkan untuk membentuk peserta didik menjadi manusia yang beriman dan bertakwa kepada Tuhan Yang Maha Esa serta berakhlak mulia. Peraturan Pemerintah Republik Indonesia Nomor 55 Tahun 2007 tentang pendidikan agama dan pendidikan keagamaan, dijelaskan dalam pasal 1 ayat (1) Pendidikan agama adalah pendidikan yang memberikan pengetahuan dan membentuk sikap, kepribadian, dan keterampilan peserta didik dalam mengamalkan ajaran agamanya, yang dilaksanakan sekurang-kurangnya melalui mata pelajaran/kuliah pada semua jalur, jenjang, dan jenis pendidikan. Ayat(2) Pendidikan keagamaan adalah pendidikan yang mempersiapkan peserta didik untuk dapat menjalankan peranan yang menuntut penguasaan pengetahuan tentang ajaran agama dan/atau menjadi ahli ilmu agama dan mengamalkan ajaran agamanya.

Selanjutnya pada Bab II pasal 2 ayat 1 dan 2, dijelaskan bahwa (1) Pendidikan agama berfungsi membentuk manusia Indonesia yang beriman dan bertakwa kepada Tuhan Yang Maha Esa serta berakhlak mulia dan mampu menjaga kedamaian dan kerukunan hubungan inter dan antar umat beragama; (2) Pendidikan agama bertujuan untuk berkembangnya kemampuan peserta didik dalam memahami, menghayati, dan mengamalkan nilai nilai agama yang 
menyerasikan penguasaannya dalam ilmu pengetahuan, teknologi dan seni.

Maka beranjak dari terminologi dan tujuan pendidikan agama sebagaiman tertuang dalam UU Sisdiknas tersebut. Pendidikan Agama Islam merupakan suatu nama kegiatan yaitu pendidikkan agama Islam (PAI) . Sehingga sama seperti mata pelajaran lainnya di sekolah seperti mata pelajaran Fisika, Biologi, Matematika dan bukan mata pelajaran pendidikan Fisika, pendidikan Biologi atau pendidikan Matematika.

Adapun karakteristik Pendidikan Agama Islam seperti yang dikemukakan oleh Muhaimin (2006: 102) adalah berusaha untuk menjaga akidah peserta didik agar tetap kokoh dalam situasi dan kondisi apapun; memelihara ajaran dan nilai-nilai yang tertuang dan terkandung dalam al-Qur'an dan hadis serta otentisitas keduanya sebagai sumber ajaran Islam; menonjolkan kesatuan iman, ilmu dan amal dalam kehidupan keseharian; berusaha membentuk dan mengembangkan kesalehan individu dan sekaligus kesalehan sosial; landasan moral dan etika dalam pengembangan iptek dan budaya serta aspekaspek kehidupan lainnya, mengandung entitas-entitas yang bersifat rasional dan supra rasional; menggali, mengembangkan dan mengambil ibrah dari sejarah dan kebudayaan (peradaban) Islam; dalam keberagaman, sehingga memerlukan sikap terbuka dan toleran atau semangat ukhuwah Islamiyah.

Menurut Majid (2005) fungsi pendidikan Agama adalah sebagai berikut: pertama, fungsi pengembangan yaitu meningkatkan keimanan dan ketaqwaan peserta didik kepada Allah SWT yang telah ditanamkan dalam lingkungan keluarga. Sekolah berfungsi untuk menumbuhkembangkan lebih lanjut dalam diri anak melalui bimbingan, pengajaran dan pelatihan agar keimanan, ketaqwaan tersebut dapat berkembang secara optimal sesuai dengan tingkat perkembangannya.

Kedua, fungsi penanaman nilai sebagai pedoman hidup untuk mencari kebahagiaan hidup di dunia dan di akhirat. Ketiga, fungsi penyesuaian mental, yaitu untuk menyesuaikan diri dengan lingkungan baik dengan lingkungan fisik maupun sosial dan dapat mengubah lingkungannya sesuai dengan ajaran agama Islam. Keempat, fungsi perbaikan, yaitu untuk memperbaiki kesalahan-kesalahan, kekurangan-kekurangan dan kelemahan-kelemahan peserta didik dalam keyakinan, pemahaman dan pengalaman ajaran dalam kehidupan seharihari. Kelima, fungsi pencegahan, yaitu menangkal hal-hal negatif dari lingkungannya atau dari budaya lain yang dapat membahayakan dirinya dan menghambat perkembangannya menuju manusia 
seutuhnya. Keenam, fungsi pengajaran tentang pengajaran ilmu pengetahuan keagamaan secara umum (alam nyata dan nirnyata), sistem dan fungsionalnya. Fungsi penyaluran, yaitu untuk menyalurkan anakanak yang memiliki bakat khusus di bidang agama Islam agar bakat tersebut dapat berkembang secara optimal sehingga dapat dimanfaatkan untuk dirinya sendiri dan bagi orang lain. Prinsip-prinsip dalam formulasi tujuan Pendidikan Islam, yang berguna untuk tercapainya tujuan pendidikan, prinsip itu adalah prinsip universal, prinsip keseimbangan dan kesederhanaan, prinsip kejelasan, prinsip tak bertentangan, prinsip realisme, prinsip perubahan yang diinginkan, prinsip menjaga perbedaan-perbedaan individu dan prinsip dinamis.

2. Implementasi PAI di Sekolah Dasar (SD) Fransiskus

SD Fransiskus yang notabenenya sekolah Kristen telah melaksanakan pembelajaran Pendidikan Agama Islam bagi siswa yang berasal dari keluarga muslim. Pelaksanaan pembelajaran PAI tersebut sudah dilaksanakan sejak sekolah tersebut berdiri. Kendatipun SD Fransiskus merupakan sekolah swasta non muslim, namun jumlah siswanya yang muslim lebih banyak dari non muslim. Menurut Kepala SD Fransiskus Lina Lindayanti Usman bahwa secara kuantitas, jumlah siswa SD Fransiskus yang berasal dari keluarga muslim lebih banyak dari anak-anak Kristen dan Katolik. Perbandingannya $60 \%$ muslim dan $40 \%$ non muslim.

Adapun Pelaksanaan secara teknis, pembelajaran PAI dilaksanakan oleh guru PAI yang sudah ditetapkan. Dari wawancara peneliti dengan Kepala Sekolah dan Guru PAI Purnama Indah Sari, S.Pd.I, dapat disimpulkan bahwa pelaksanaan PAI sama dengan yang dilaksanakan pada SD lain yang ada di Kota Padang Panjang yaitu dengan berpedoman kepada kurikulum nasional PAI. Hanya saja, tekniknya pada saat mata pelajaran agama siswa dipisahkan menurut agamanya masing-masing. Siswa yang beragama Islam pada satu ruang dan yang non muslim juga demikian. Begitu juga dalam pelaksanaan praktek-praktek keagamaan seperti berwudhuk, shalat, penyelenggaraan jenazah, sudah difasilitasi oleh sekolah dengan memanfaatkan ruang belajar dan ruang baca yang tersedia di komplek sekolah. Di samping melaksanakan Pendidikan Agama Islam yang berpedoman pada kurikulum nasional, SD Fransiskus juga mengakomodir kurikulum yang merupakan kearifan lokal di kota Padang Panjang, yaitu mata pelajaran pendidikan al-Qur'an dan melaksanakan program tahfizh al-Qur'an. Namun karena keterbatasan waktu belajar di sekolah, pihak sekolah telah menganjurkan kepada orang tua yang muslim untuk menambah pelajaran al- 
Qur'an dan tahfizh di Taman Pendidikan AlQur'an yang ada di luar sekolah, atau dengan mendatangkan guru privat ke rumah.

Secara teknis, pelaksanakan Pendidikan Agama Islam di SD Fransiskus tidak begitu mengalami persoalan. Kendatipun harus diakui bahwa dengan label sekolah swasta bercirikan agama non muslim, sejauh ini perbedaan keyakinan (agama) siswa maupun guru, tidak menghalangi untuk proses sosialisasi dan pembelajaran. Menurut Kepala Sekolah, kalaupun ada indikasi pergesekan di kalangan siswa karena perbedaan agama tersebut, namun dapat di atasi segera. Pihak sekolah sejak dini sudah mengajarkan dan menanamkan sikap toleransi antar pemeluk agama yang berbeda.

Penelitian ini didukung oleh pertama, penelitian Syafrilsyah dan Mauliana (2015) penelitiannya berjudul Sikap Toleransi Beragama di Kalangan siswa SMA di Banda Aceh, hasil penelitiannya menunjukkan bahwa sikap siswa di kedua sekolah sangat fleksibel dalam hubungan antara Muslim dan siswa non-Muslim, baik di SMA 3 Banda Aceh ataupun di SMA Methodist, perlakuan siswa terhadap siswa yang bebeda agama adalah sama tanpa perbedaan, baik pada kebutuhan mental dan pembelajaran. Siswa saling menghormati satu sama lain, saling menghormati satu sama perbedaan, mengakui dan mengizinkan hak yang ada pada masing- masing agama. Siswa dari kedua sekolah menunjukkan sikap antusias dalam membangun persahabatan. Perbedaan agama tidak menjadi dinding pemisah di antara mereka. Solidaritas di kalangan siswa dibangun di atas sikap toleransi dalam kehidupan sehari-hari di sekolah.

Kedua, penelitian Rofiqoh (2015) hasil penelitian ini menunjukkan bahwa sikap siswa di kedua sekolah sangat fleksibel dalam hubungan antara Muslim dan siswa nonMuslim, baik di SMA 3 Banda Aceh ataupun di SMA Methodist, perlakuan siswa terhadap siswa yang bebeda agama adalah sama tanpa perbedaan, baik pada kebutuhan mental dan pembelajaran. Siswa saling menghormati satu sama lain, saling menghormati satu sama perbedaan, mengakui dan mengizinkan hak yang ada pada masing-masing agama. Siswa dari kedua sekolah menunjukkan sikap antusias dalam membangun persahabatan. Perbedaan agama tidak menjadi dinding pemisah di antara mereka. Solidaritas di kalangan siswa dibangun di atas sikap toleransi dalam kehidupan sehari-hari di sekolah. Perbedaan penelitian ini dengan penelitian terdahulu penelitian ini lebih memfokuskan pada implementasi pembelajaran PAI pada pendidikan dasar, sementara penelitian sebelumnya lebih mengkaji konsep pluralitas pada sekolah menengah. Persamaan penelitian terdapat 
pada toleransi beragama yang diterapkan pada setiap sekolah.

Ketiga, penelitian Mawardi (2013) hasil penelitiannya menunjukkan pentingnya pembelajaran PAI bagi peserta didik, sebagai gawang iman dan akhlak yang akan mendasari seluruh aktifitas kehidupan dan tentunya akan membawa pengaruh yang besar dalam mempersiapkan generasi yang kuat dan handal, terutama komitmen iman dan takwa serta dibarengi nilai-nilai luhur akhlakul karimah dalam dialektika hidup berbangsa dan bernegara. Oleh sebab itu pembelajaran PAI di sekolah formal mendapat jaminan dalam Undang-Undang. PAI sendiri adalah pendidikan yang dilaksanakan berdasarkan ajaran Islam yang berupa bimbingan dan asuhan terhadap anak didik agar nantinya setelah selesai dari pendidikan ia dapat memahami, menghayati dan mengamalkan ajaran-ajaran agama Islam yang telah diyakininya secara meyeluruh, serta menjadikannya ajaran agama Islam itu sebagai suatu pandangan hidupnya demi keselamatan hidup di dunia maupun di akhirat kelak.

\section{KESIMPULAN}

Keberadaan Indonesia yang majemuk, plural dan multikultural, menghendaki pengelolaan yang baik, sehingga terhindar dari gesekan dan konflik. Potensi konflik yang sangat rentan adalah perbedaan keyakinan/ agama. Salah satu langkah untuk meminimalisir petensi konflik tersebut adalah melalui jalur pendidikan, terutama pada pendidikan agama. Mengacu kepada Undangundang Sistem Pendidikan Nasional Nomor 20 tahun 2003 bahwa setiap sekolah berkewajiban memberikan Pendidikan Agama sesuai dengan agama peserta didik oleh guru yang seagama. Hal ini menjadi penting, karena rawannya persoalan agama menyulut pertikaian dan perbuatan intoleran.

Sekolah Dasar (SD) Fransiskus Kota Padang Panjang sebagai sekolah bercirikan agama non Islam, telah melaksanakan pembelajaran Pendidikan Agama Islam bagi peserta didik yang muslim. SD Fransiskus juga melaksanakan kebijakan lokal yaitu Pemerintah Kota Padang Panjang, dalam hal pelaksanaan kurikulum pendidikan al-Qur'an dan program tahfizh yang merupakan salah satu bentuk kearifan lokal. Dengan demikian, lingkungan pendidikan yang dihuni oleh peserta didik dan guru yang berbeda keyakinan telah tertanam sikap saling menghormati dan toleransi.

\section{DAFTAR PUSTAKA}

Al-Qur'an dan Terjemahan

Mulkhan, Abdul Munir. (2005). Kesalehan Multikultural. Jakarta: Pusat Studi Agama dan Peradaban Muhammadiyah 
Dawam, Ain al-Rafiq. (2003). Emoh Sekolah. Yogyakarta: Inspeal Ahimsa Karya Press.

Amstrong, Karen. (2001). Sejarah Tuhan; Kisah Pencarian Tuhan yang di Lakukan oleh Orang-Orang Yahudi, Kristen dan Islam selama 4000 Tahun, terj. Zaimul Am, Bandung: Mizan.

Azizy, Qodri A. (2005). Harmoni Kehidupan Beragama. Yogyakarta: Oasis Publisher.

Mahfud, Choirul. (2006). Pendidikan Multikultural. Yogyakarta: Pustaka Pelajar

Madjid, Abdul dan Andiyani, Dian. (2004). Pendidikan Agama Islam Berbasiskan Kompetensi (Konsep dan Implementasi Kurikulum 2004). Bandung: Remaja Rosda Karya

- (2005). Pendidikan Agama Islam Berbasis Kompetensi. Bandung: Remaja Rosdakarya
Muhaimin. (2006). Nuansa Baru Pendidikan Islam: Mengurai Benang Kusut Dunia Pendidikan. Jakarta: Raja Grafindo Persada.

Sisdiknas, (2010). Undang-undang Sistem Pendidikan Nasional. Bandung: Fokusmedia

Sukardi. (2008). Metodologi Penelitian Pendidikan. Jakarta: Bumi Aksara

Tilaar, H.A.R. (2014). Multikulturalisme, Tantangan-tangan Global Masa Depan dalam Transformasi Pendidikan Nasional, Jakarta: PT Grasindo, 2014

Tim Penyusun Kamus Pusat Bahasa. (2008). Kamus Bahasa Indonesia. (Jakarta: Pusat Bahasa.

Yusuf, Choirul Fuad. (2006). Edukasi Jurnal Penelitian Pendidikan dan Keagamaan. Jakarta: Badan Litbang dan Diklat Depag RI 